DOI: https://doi.org/10.36910/6775-2524-0560-2020-41-27

УДК: 004.65

${ }^{1}$ Кузьмич Олена Іванівна, к. ф.-м. н., доцент

https://orcid.org/0000-0002-8717-4497

${ }^{1}$ Багнюк Наталія Володимирівна, к. т. н., доцент

https://orcid.org/0000-0002-7120-5455

${ }^{2}$ Мекуш Оксана Григорівна

https://orcid.org/0000-0001-6052-9211

${ }_{1}^{1}$ Бортник Катерина Яківна, к.т.н.,доцент

http://orcid.org/0000-0001-5282-099X

${ }^{1}$ Марчук Богдан Ігорович, студент

${ }^{1}$ Луцький національний технічний університет,

${ }^{2}$ Волинський національний університет імені Лесі Українки, м. Луцьк, Україна

\title{
МЕТОДИ СИНХРОНІЗАЦІЇ БАЗ ДАНИХ ПЛАТФОРМ ІНТЕРНЕТ-КОМЕРЦІї ЗАСОБАМИ 1C-БITPIKC
}

Кузьмич О.І., Багнюк Н.В., Мекуш О.Г., Бортник К.Я., Марчук Б.І. Методи синхронізації баз даних платформ інтернет-комерції засобами 1C-Бітрікс. В даній статті проведено аналіз методів оптимізації обліку торгового підприємства шляхом синхронізації баз данних 1С та інтернет магазину. Проведено огляд, дослідження і застосування систем синхронізації даних.. Зроблено SWOT-аналіз процесу використання інтернет-магазину на платформі 1C- Бітрікс.

Ключові слова: інтернет магазин, синхронізація бази даних, 1С Підприємство.

Кузьмич Е.И., Багнюк Н.В., Мекуш О.Г., Бортник Е.Я., Марчук Б.И.. Методы синхронизации баз данных платформ интернет-коммерции средствами 1С-Битрикс. В данной статье проведен анализ методов оптимизации учета торгового предприятия путем синхронизации баз данных 1С и интернет магазина. Проведен обзор, исследование и применение систем синхронизации данных .Сделано SWOT-анализ процесса использования интернет-магазина на платформе 1С-Битрикс..

Ключевые слова: интернет магазин, синхронизация базы данных, 1С Предприятие.

Kuzmych O.I., Bahniuk N.V., Mekush O.G., Bortnyk K., Marchuk B.I. Methods of synchronization of databases of ecommerce platforms by means of 1C-Bitrix. In the given article the analysis of methods of optimization of the account of the trading enterprise by synchronization of databases $1 \mathrm{C}$ and online store is carried out. A review and realization of data synchronization systems was performed. A SWOT analysis of the process of using the online store on the 1C-Bitrix platform was made.

Keywords: online store, database synchronization, 1C Enterprise.

\section{Постановка наукової проблеми}

Інтернет-торгівля як процес реалізації і збуту товарів та послуг за допомогою спеціалізованих електронних майданчиків, які реалізують дистанційне оформлення замовлення та доставку набуває сьогодні все більших масштабів. Торгівельні інтернет-майданчики в Україні, які в світі, розвиваються досить успішно, адже за підсумками досліджень ринку обсяг інтернет-продажів постійно збільшується так само як і збільшується кількість інтернет-магазинів. Якщо виникає необхідність в системі управління і оперування великими обсягами товарів, то виникає проблема впровадження ефективного автоматизованого механізму, який може бути реалізований, наприклад, засобами $1 \mathrm{C}$ як багатофункціональної системи, призначеної для вирішення багатьох завдань, включаючи фінансові розрахунки, менеджмент персоналу, формування списків товарів і послуг. Коли виникає завдання побудови інтернет-магазину, виникає проблема ефективних способів отримання, актуалізації, оновлення даних з 1С. В контексті цього, виникає необхідість у створенні модуля забезпечення синхронізації баз даних 1С Підприємства та інтернет магазину.

Типового модуля, який би дозволив завантажувати актуальні дані з будь-якого інтернетмагазину, в будь-яку програму $1 \mathrm{C}$, на жаль, насьогодні не існує. Це обумовлено варіативністю програм 1C: торгівля, управління торговим підприємством, управління виробничим підприємством, управління невеликою фірмою. Також існують різні системи, які використовуються на сайтах і для кожної необхідний свій підхід. Тому представлене в статті дослідження присвячене актуальній проблемі аналізу методів синхронізації даних інтернет-магазину з даними бухгалтерського та оперативного обліку підприємства. Найкращим варіантом системи обліку для більшості інтернетмагазинів є 1C - програма для автоматизації роботи підприємств, що дозволяє якісно вирішити проблему обліку товарів, замовлень і ефективно побудувати документообіг. Тому реалізація цього завдання виконана на прикладі синхронізації бази 1С Підприємство з інтернет-магазином одягу.

Аналіз досліджень 
Аналіз заявленої проблематики показує, що до стратегічних цілей розробників продуктів $1 \mathrm{C}$ відносяться такі як налаштовування конфігурацій, розробка готових рішень функціонування автоматизованої інформаційної системи підприємства, реалізація звітів і підсумків за рахунками, інші важливі завдання. В контексті завдання вибору платформи, програма 1С вибрана в якості засобу проектування бізнес-додатків, а також проаналізовано 1С-Бітрікс в якості системи управління вебпроектами. Під час детального аналізу методів синхронізації інфо-бази 1 С встановлено, що важливим моментом є реалізація взаємодії між платформою 1C і зовнішньою інформаційною системою, яка реалізується двома механізмами: зовнішнім з'єднанням і через web-сервіс. При цьому реалізуються можливості використання HTTP-сервісів та підтримка REST-інтерфейсу в 1C із застосуванням формату XML. Серед найбільш поширених фреймворків можна виділити Symphony, Zend, Yii, Doctrine, Smarty, Drupal, Wordpress, а серед використовуваних серверних мов можна виділити Ruby, ASP, JSP, Python, Perl. В контексті реалізації заявленого функціоналу придатними системами управління БД є MySQL, PostgreSQL, ORACLE, використовується формат CommerceML в 1C.

За підсумками 2019 р. обсяг ринку інтернет-торгівлі перевищив 1537 млрд. дол. Також протягом останніх 5 років він зростав у середньому на 42,2\% на рік. Експерти компанії J'son \& Partners Consulting розглянули 172 компанії в 20 сегментах інтернет-торгівлі, і виявили що найбільшими областями світової інтернет-торгівлі $є$ «електроніка, побутова техніка» $(1125,5$ млрд. дол.), «гіпермаркети» (185 млрд. дол.), «взуття і одяг» (174,2 млрд. дол.). Крім того, ринок інтернетторгівлі в Україні за підсумками 2019 р. склав 26\% від загального інтернет-ринку [6].

Під час аналізу і дослідження предметної області було проаналізована проблему синхронізації даних між 1C та стороннім web-додатком, проведено огляд існуючих на ринку актуальних систем синхронізації даних. При огляді аналогів, були виявлені їх переваги та недоліки, цей аналіз був здійснений на основі даних з джерел [1-3]. На базі даного аналізу, в даній статті ми досліджуєм матеріальні затрати на створення даних додатків та реалізовуємо SWOT-аналіз процесу використання інтернет-магазину на платформі 1C: Бітрікс. Необхідні дані і інформація для аналізу отримана 3 [4$5]$.

\section{Виклад основного матеріалу й обгрунтування отриманих результатів}

Автоматизація системи бухгалтерського обліку дозволяє полегшити роботу бухгалтера, позбутися рутинної роботи, підвищує точність облікової інформації, дозволяє проведення економічного і фінансового аналізу роботи підприємства та пошуку шляхів підвищення ефективності цієї роботи. Інформаційні системи на базі «1С: Підприємство» - це універсальні програми масового призначення, складовими їх є технологічна платформа та конфігурації. Особливістю їх є можливість розробки або зміни конфігурації користувачами системи або організаціями, що спеціалізуються на впровадженні та підтримці системи. Ця можливість дозволяє забезпечити максимальну відповідність системи особливостям обліку на конкретному підприємстві.

Важливим моментом при розгляді методів синхронізації є реалізація взаємодії між платформою $1 \mathrm{C}$ і зовнішньою інформаційною системою, яка може бути виконана двома основними механізмами: зовнішнім з'єднанням і web-сервісом.

Зовнішнє з'єднання є одним з механізмів інтеграції, що реалізується на СОМ-об'єктах. Для роботи через зовнішнє з'єднання необхідно створити менеджер СОМ-з'єднань, за допомогою якого встановлюється з'єднання. Зазвичай такий механізм використовується для взаємодії між різними конфігураціями 1С. Хоча вони доступні для роботи тільки на серверах 3 OC Microsoft Windows Server, інші не підтримуються.

Інший механізм, що дозволяє налаштувати інтеграцію, - web-сервіс. Даний механізм є новіший, тому ще не має достатнього поширення, незважаючи на переваги. Web-сервіс $\epsilon$ елементом конфігурації, що має свій модуль. У модулі вказуються методи роботи з web-сервісом, які можуть бути викликані при підключенні. Ці методи можуть повертати дані в будь-якому форматі.

Web-сервіси є засобом підтримки сервіс-орієнтованої архітектури (SOA), що є сучасним стандартом інтеграції інформаційних систем. Підключення реалізується по протоколу SOAP i $\epsilon$ кроссплатформенним. Механізм web-сервісу $\epsilon$ сучасним i має переваги за всіма критеріями порівняння. Таким чином, даний механізм є оптимальним для інтеграції платформи 1С і зовнішніх систем. Впровадження змін може проводитися безпосереднім редагуванням типової конфігурації або використанням механізму розширень.

На підставі проведеного порівняльного аналізу було прийнято рішення, що для реалізації інтеграції платформи $1 \mathrm{C}$ із зовнішніми інформаційними системами оптимальним варіантом $\epsilon$ внесення змін до типової конфігурації. Передача даних між базою 1C і базою даних зовнішньої системи може бути реалізована двома основними механізмами: за допомогою зовнішнього з'єднання з використанням СОМ-об'єктів або з використанням елемента конфігурації web-сервіс, що здійснює 
обмін даними через протокол SOAP. За даними порівняльного аналізу з урахуванням необхідності розробки уніфікованого кроссплатформенного рішення можна зробити висновок про те, що оптимальним рішенням є використання web-сервісу .

Таким чином, для вирішення завдання інтеграції слід вносити зміни в типову конфігурацію, а обмін даними здійснювати за допомогою web-сервісу.

Сучасні динамічні сайти використовують базу даних для зберігання свого контенту і для реалізації функцій. Найбільш поширеними СУБД $є$ MySQL, PostgreSQL, ORACLE, які $\epsilon$ полегшеними, тобто володіють обмеженим функціоналом, достатнім для веб-розробки. В контексті цього найбільш поширеною $\epsilon$ MySQL, оскільки вона $є$ простою у використанні і володіє високою швидкістю обробки запитів. Це $\epsilon$ важливо при значній кількості звернення користувачів до сервера сайту. Зв'язка PHP + MySQL є найбільш поширеною у back-end розробці, так як PHP має достатньо засобів для організації масштабної роботи з базою даних. В процесі синхронізації 1C вивантажує файли формату .txt, .xml або .csv, які передаються на веб-сайт по протоколах http або ftp. В подальшому веб-ресурс обробляє отримані файли. Такий реалізований вручну обмін даних дозволяє досить гнучко описати всі правила і алгоритми обміну. Відмітимо, що він добре функціонує при обміні невеликими обсягами даних, в той час як при великих обсягах виникають проблеми 3 продуктивністю.

У Таблиці 1 наведено порівняння наведених функціональних механізмів за такими параметрами як безпека даних, продуктивність, відмовостійкість.

\section{Таблиия 1}

Порівняння механізмів обміну даними

\begin{tabular}{|c|c|c|}
\hline Тип обміну & Переваги & Недоліки \\
\hline CommerceML & $\begin{array}{l}\text { - С в стандартних } \\
\text { рішеннях 1С. } \\
\text { - Немає доступу в базу } \\
1 \text { С з інтернет, } \\
\text { - Прийнятний рівень } \\
\text { безпеки, }\end{array}$ & $\begin{array}{l}\text { При роботі по схемі Постачальник-Покупець потрібно } \\
\text { вручну ініціювати обмін. } \\
\text { Надмірність даних протоколу призводить до зниження } \\
\text { продуктивності. } \\
\text { Дані не зашифровані. } \\
\text { Великі обсяги даних можуть призвести до відмови в } \\
\text { роботі. } \\
\text { Немає стандартизованих засобів автоматичного } \\
\text { моніторингу процесу обміну. }\end{array}$ \\
\hline $\begin{array}{c}\text { Web - } \\
\text { розширення }\end{array}$ & $\begin{array}{l}\text { - Прямий доступ в базу } \\
\text { 1с дозволяє спростити } \\
\text { процес налагодження. } \\
\text { - Включено в деякі } \\
\text { стандартні поставки. }\end{array}$ & $\begin{array}{l}\text { Під кожного користувача потрібно купувати ліцензію } \\
1 \mathrm{C} \text {. } \\
\text { Продуктивність залежить від швидкості доступу до } \\
\text { бази } 1 \mathrm{C} \text {. } \\
\text { Прямий доступ в базу, загроза доступу до даних } 1 \text { С } 3 \\
\text { інтернет. } \\
\text { Відмова роботи сервера } 1 \mathrm{C} \text { викличе відмову роботи } \\
\text { сайту. }\end{array}$ \\
\hline $\begin{array}{l}\text { Підключення } \\
\text { DLL }\end{array}$ & $\begin{array}{l}\text { - Продуктивність } \\
\text { залежить тільки від } \\
\text { обсягу даних } \\
\text { - Прийнятний рівень } \\
\text { безпеки, доступу в базу } \\
\text { 1С з інтернет немає. } \\
\text { - Трафік шифрується при } \\
\text { обміні через протокол } \\
\text { sftр. } \\
\text { - Висока } \\
\text { відмовостійкість при } \\
\text { передачі великих об’ємів } \\
\text { даних. }\end{array}$ & $\begin{array}{l}\text { Трудомістке написання і реалізація бібліотеки. } \\
\text { Підійде тільки для реалізації транспорту даних. }\end{array}$ \\
\hline $\begin{array}{l}\text { СОМ- } \\
\text { інтерфейс }\end{array}$ & $\begin{array}{l}\text { Прийнятний рівень } \\
\text { безпеки, доступу в базу } \\
1 \text { С з інтернет немає. }\end{array}$ & $\begin{array}{l}\text { Продуктивність залежить від швидкості доступу до } \\
\text { бази 1С. } \\
\text { Можливі збої роботи при частих таймаутах. } \\
\text { Трудомістке написання СОМ інтерфейсу. }\end{array}$ \\
\hline $\begin{array}{l}\text { Web-сервіси } \\
1 \mathrm{C}\end{array}$ & $\begin{array}{l}\text { Прямий доступ в базу 1с } \\
\text { дозволяє спростити } \\
\text { процес налагодження. }\end{array}$ & $\begin{array}{l}\text { Продуктивність сильно залежить від швидкості } \\
\text { доступу до бази 1С. } \\
\text { Відкриті порти доступу в базу } 1 \mathrm{C}, \epsilon \text { потенційні } \\
\text { загрози. } \\
\text { Можливі відмови в роботі при збоях в базі } 1 \mathrm{C} \text {. }\end{array}$ \\
\hline
\end{tabular}


Науковий журнал "Комп'ютерно-інтегровані технології: освіта, наука, виробництвво" Луиььк, 2020. Випуск № 41

\begin{tabular}{|c|c|c|}
\hline $1 \mathrm{C} 8.3$ & $\begin{array}{lr}\text { Високий } & \text { ступінь } \\
\text { безпеки, } & \text { підтримка } \\
\text { протоколів шифрування. }\end{array}$ & Необхідна міграція з поточної платформи 1С. \\
\hline $\begin{array}{c}\text { Універсальний } \\
\text { обмін XML }\end{array}$ & $\begin{array}{l}\text { Прийнятний рівень } \\
\text { безпеки, доступу до бази } \\
\text { 1С з інтернет немає. }\end{array}$ & $\begin{array}{l}\text { Ініціація обміну за замовчуванням здійснюється } \\
\text { оператором. Обробка великих файлів правил сильно } \\
\text { знижує продуктивність. Дані передаються у } \\
\text { відкритому вигляді. При великих обсягах даних } \\
\text { можливі збої. }\end{array}$ \\
\hline $\begin{array}{c}\text { Веб-сервер на } \\
\text { стороні 1C }\end{array}$ & $\begin{array}{l}\text { - Немає промислових } \\
\text { впроваджень. } \\
\text { - Рішення на рівні } \\
\text { прототипу. }\end{array}$ & $\begin{array}{l}\text { Продуктивність нижче, ніж у звичайних веб- серверів } \\
\text { Низький рівень безпеки, відкритий порт доступу до } \\
\text { бази даних } 1 \mathrm{C} \text {. } \\
\text { Сайт не працює при збоях з базою } 1 \mathrm{C} \text {. }\end{array}$ \\
\hline
\end{tabular}

Проведемо аналіз технології «Веб-сервер на стороні 1C». Механізм web-сервісів, який вбудований в платформу 1С: Підприємство дозволяє створити конфігурацію з повнофункціональною CMS-системою, що генерує по запиту html-код. Таким чином, в цілому вирішується задача обміну даними 3 сайтом, він по суті інтегрований, так як сайт працює на базі 1С. Розглянутий механізм потенційно володіє низькою продуктивністю.

Кожен 3 описаних варіантів має певні як переваги, так і недоліки (див. Таблицю 1). Таким чином, вибір конкретного механізму в кінцевому рахунку залежить від багатьох факторів i вирішується індивідуально. Практичний досвід показує, що найбільш оптимальним є рішення, яке використовує одночасно кілька варіантів обміну для різних ситуацій. В процесі вибору варіанту обміну, що використовується в масштабному проекті для створення функціонуючої $b 2 b$ системи, що реалізовує універсальну інтеграцію в більшість відомих конфігурацій $1 \mathrm{C}$, то зазвичай обирається формат CommerceML 3 допрацьованим функціоналом. Вибір базується на поєднанні гнучкості налаштування універсального обміну XML, якісної автоматизації і підвищеної продуктивності.

В результаті цього аналізу у представленій роботі ми використали оптимізований CommerceML, як формат для обміну даними сайту з базами 1C Підприємство. При цьому доступна можливість гнучкого налаштування об'єктів обміну даними без програмування, через додавання необхідних об'єктів в пакет XDTO.

\section{Особливості розробки інтернет-магазину на платформі 1С-Бітрікс}

Реалізований в межах дослідження інтернет-магазин розглянемо як прикладну демонстраційну систему синхронізації, який в контексті задачі також виконує функцію представлення товарів, обробку замовлень, продаж, доставку товарів. Проведення інтеграції інтернет-магазину 3 платформою $1 \mathrm{C}$ реалізовує завантаження товарів в автоматичному режимі з 1С на сайт 3 описами, зазначенням всіх наявних характеристик. Синхронізація сайту з платформою 1С дає можливість актуально відображати всі необхідні відомості про залишки товару, а отже, і всі дані у каталогах інтернет-магазину будуть своєчасно оновлюватися. Всі замовлення і персональні дані замовників на платформу $1 \mathrm{C}$ будуть переноситися в автоматичному режимі. Замовники завжди в курсі того, на якій стадії обробки знаходиться їх замовлення. Для інтернет-магазинів процес синхронізації також має такі переваги як іІстотна економія часу співробітників, кількість помилок буде зведено до мінімуму, оскільки інформації, що вводиться вручну буде дуже мало, замовлення будуть оброблятися набагато швидше. Відвідувачі завжди будуть бачити актуальну інформацію по наявності товарів i їх складським залишкам, а значить, відсутніх товарів замовляти не будуть.

\section{Архітектурне проектування програмного модуля}

Розглянемо основні етапи обміну даними. Процес обміну даними між програмними системами складається з 3 основних частин: ініціація обміну; вивантаження даних на сайт; вивантаження даних 3 сайту. Ініціація - це важливий етап, основна частина роботи в рамках якого, проводиться до першого вивантаження даних на сайт. Необхідно налаштувати бази даних під певні стандарти, перевірити інформацію щоб не вивантажувати помилкові або надмірні дані. Далі на наступних етапах обмін буде здійснюватися автоматично і регулярно. Але перше вивантаження даних повинно бути відповідним чином підготовлене, і тільки потім обмін ініціюється - проводиться перше вивантаження і після перевірок включається постійний обмін. Розроблювана система синхронізації даних має складатися 3 таких модулів як модуль зміни конфігурації; модуль зміни даних; розмежування прав доступу користувачів; модуль додавання користувачів; модуль присвоєння прав доступу; синхронізація, модуль парсингу файлів, модуль збору статистики.

Загальний алгоритм звернення та функціонування web-сайту складається з наступних дій:

- Користувач робить GET-запит на сервер. Для реалізації запиту, браузер використовує НTTP; 
- Сервер обробляє GET-запит: при цьому якщо запитувана сторінка існує - сервер повертає HTML розмітку, якщо вона не існує - сервер повертає код помилки;

- Браузер обробляє відповідь і відображає номер помилки.

Розглянемо блок-схему загального алгоритму роботи системи синхронізації даних 3 1C, яка зображена на рисунку 1.

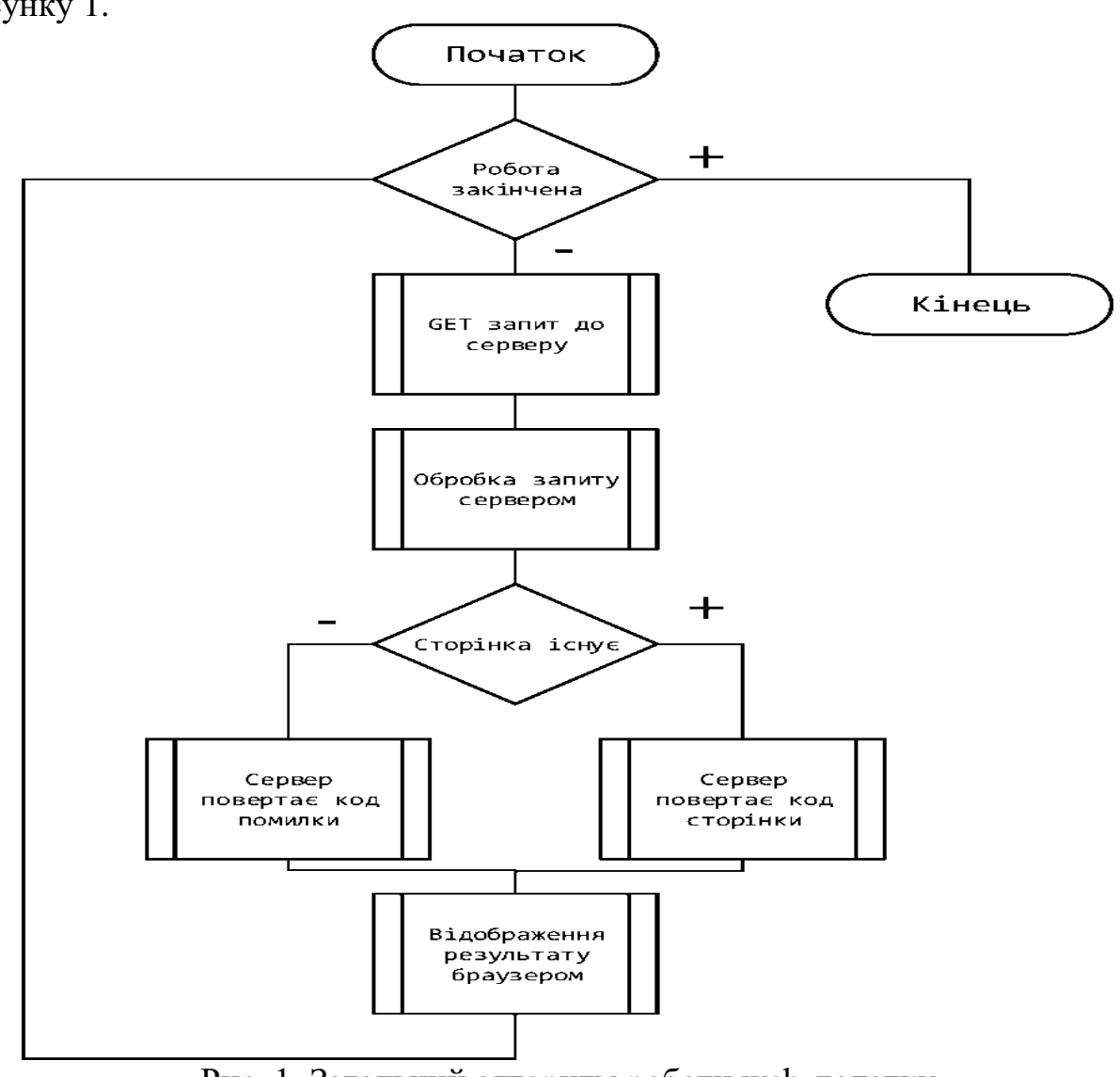

Алгоритм зміни конфігурацій працює наступним чином:

- Користувач авторизується у системі, проходить аутентифікацію;

- Користувач відправляє GET - запит до сервера, отримує список доступних конфігурацій;

- Користувач змінює конфігурацію та зберігає іï, на сервер відправляється POST - запит;

- Сервер змінює конфігурацію і зберігає ії.

Оцінка ефективності та SWOT-аналіз.

Для тестування працездатності були обрані найбільш популярні браузери, а саме «Chrome», «Mozilla», «Internet Explorer». На першому етапі проводилося функціональне тестування ключових елементів. Для тестування даного блоку використовувався «Яндекс Браузер». Для тестування були в кошик були додані 2 товари. В результаті тестування відображення сайту в браузерах робимо висновок про коректність виведення інформації в них. Проведемо SWOT-аналіз процесу використання інтернет-магазину на платформі 1C: Бітрікс, який $є$ одним 3 найпоширеніших методів аналізу і стратегічного планування і дає чітке уявлення про фактори середовища, вказує в яких напрямках потрібно діяти щоб максимізувати можливості і звести до мінімуму загрози. За допомогою цього методу можна визначити перспективу розвитку проекту автоматизації. Результатом аналізу $є$ розробка маркетингової стратегії або гіпотези для подальшої перевірки, вони представлені в Таблиці 2. Таким чином, в результаті SWOT-аналізу були розглянуті сильні і слабкі сторони розробки інформаційної системи, виявлені можливі перспективи іiі створення і розглянуті варіанти мінімізації впливу загроз, які можуть цьому перешкодити. Для підвищення ефективності роботи програми необхідно мінімізувати помилки, контролювати процес створення і перевіряти роботу системи відповідно до поставлених вимог. 
Таблиия 2

\section{Результати SWOT-аналізу}

\begin{tabular}{|c|c|c|}
\hline 1 & 2 & 3 \\
\hline & $\begin{array}{l}\text { Можсливість: } \\
\text { 1. Інтеграція з 1C } \\
\text { 2. Автоматизація обліку }\end{array}$ & $\begin{array}{l}\text { 3агроза: } \\
\text { 1) збої в роботі системи. } \\
\text { 2) проблеми синхронізації з 1С } \\
\text { 3) Зміна законодавства. }\end{array}$ \\
\hline $\begin{array}{l}\text { Cильні сторони: } \\
\text { 1) зручність представлення } \\
\text { даних. } \\
\text { 2) автоматичний збір } \\
\text { статистики. } \\
\text { 3) спрощення процедури } \\
\text { покупки. } \\
\text { 4) Надійність системи } \\
\end{array}$ & $\begin{array}{l}\text { Як скористатися } \\
\text { можсливостями } \\
\text { 1. Провести роботу по } \\
\text { створенню правил обміну для } \\
\text { зв'язку з 1С. } \\
\text { 2. Налаштувати Раннє створені } \\
\text { правила обм }\end{array}$ & $\begin{array}{l}\text { За рахунок чого можсна знизити } \\
\text { загрози } \\
\text { 1. Оренда надійного сервера або } \\
\text { покупка власного. } \\
\text { 2. Розміщення 1С на надійному } \\
\text { сервері з постійною підтримкою. } \\
\text { 3. Розробка сприйнятливої до змін } \\
\text { системи. }\end{array}$ \\
\hline $\begin{array}{l}\text { Слабкі сторони: } \\
\text { 1. Залежність від сервера. } \\
\text { 2. Залежність від мережі } \\
\text { Інтернет. }\end{array}$ & $\begin{array}{l}\text { Що може перешкодити } \\
\text { можжливостялм } \\
\text { 1. Проблеми з серверним } \\
\text { обладнанням можуть вплинути } \\
\text { на працездатність сайту. }\end{array}$ & $\begin{array}{l}\text { Найбільші небезпеки для фірми } \\
\text { 1. Розроблений інтернетмагазин не } \\
\text { буде відповідати вимогам. } \\
\text { 2. Час, витрачений на його } \\
\text { створення, буде втрачено даремно. }\end{array}$ \\
\hline
\end{tabular}

\section{Висновки та перспективи подальшого дослідження.}

В даній статті проаналізовано проблему синхронізації даних між 1С та веб-сайтом. При цьому проведено аналіз доступних систем синхронізації даних, виявлено їх переваги та недоліки. В практичній частині дослідження описано особливості розробки типового інтернет-магазину та платформі 1С-Бітрікс, в контексті цього - деталізовано основні етапи процесу, розглянуто механізми реалізації, досліджено структуру інтернет-магазину, проведено проектування бази даних та механізму синхронізації. Також проведено розробку демонстраційного програмного модуля для синхронізації інтернет-магазину з базою 1C, визначено переваги такої синхронізації. Окремо досліджено матеріальні затрати на створення такого механізму та зроблено SWOT-аналіз процесу синхронізації інтернет-магазину на платформі 1C: Бітрікс. Ефективна синхронізація має значні переваги - це автоматичне завантаження товарів з $1 \mathrm{C}$ на сайт разом з усіма необхідними даними $\mathrm{i}$ параметрами. Синхронізований з $1 \mathrm{C}$ сайт завжди підтримує актуальність даних про залишки товару, відповідно, вирішується питання своєчасності і актуальності оновлення каталогів інтернет-магазину. Замовлення і дані клієнтів також переносяться в 1С автоматично. В результаті, інтеграція інтернетмагазину з $1 \mathrm{C}$ дозволяє значно заощадити час роботи, з іiі допомогою стає можливим мінімізувати кількість помилок ручного введення. Додатковою перевагою стає збільшення швидкості обробки замовлень, адже менеджер не витрачає час на перенесення даних клієнта з сайту в 1C, а відразу може побачити замовлення в даній системі обліку.

Список бібліографічного опису.

1. Акила К., Еремеевский А. Интернет-магазин с нуля. Полное пошаговое руководство; Питер - Москва, 2013.176 с.

2. Ашманов І. С., Іванов А. А. Просування сайту в пошукових системах. М.: Вільямс, 2007. 304 с.

3. Байков В. Интернет. Поиск информации и продвижение сайтов; БХВ-Петербург-М., 2013. 288 с.

4. Богачова Т. Г. 1С: Підприємство 8. Управління торговими операціями в питаннях і відповідях. Вид-во: 1С-Паблішинг, 2014. $210 \mathrm{c}$.

5. Вендров А. М. CASE-технології. Сучасні методи і засоби проектування інформаційних систем. М.: Фінанси та статистика, 2018. $176 \mathrm{c.}$

6. Шквір В. Д. Інформаційні системи і технології в обліку: навч. посібник / В.Д. Шквір, А.Г. Загородній, О.С. Височан. Львів: Видавництво Національного університету «Львівська політехніка», 2007. 439 с.

\section{References}

1. Akila K., Eremeevsky A. Online store from zero. Complete step-by-step guide; Peter - Moscow, 2013. 176 p.

2. Ashmanov I.S., Ivanov A.A. Web-site promotion in search engines. M .: Williams, 2007. 304 p.

3. Baikov V. Internet. Search for information and promotion of sites; BHV-Petersburg-M., 2013. 288 p.

4. Bogachova T.G. 1C: Enterprise 8. Management of trade operations in questions and answers. Publisher: 1C-Publishing, 2014. 210 p.

5. Vendrov A.M. CASE-technology. Modern methods and tools for designing information systems. M .: Finance and Statistics, 2018. $176 \mathrm{p}$.

6. Shkvir V.D. Information systems and technologies in accounting: textbook. manual / VD Shkvir, A.G. Zagorodniy, OS High. Lviv: Lviv Polytechnic National University Publishing House, 2007. 439 p. 